\title{
Consumption of Renewable Energy and Economic Growth
}

\author{
Agnė Šimelyté ${ }^{1}$, Gitana Dudzevičiūté $\dot{2}^{2,3}$ \\ ${ }^{1,2}$ Department of Economics and Management of Enterprises, Faculty of Business Management, \\ Vilnius Gediminas Technical University, Vilnius, Lithuania \\ ${ }^{3}$ Department of Management, The General Jonas Žemaitis Military Academy of Lithuania, Vilnius, Lithuania \\ E-mails: ${ }^{1}$ agne.simelyte@vgtu.lt (corresponding author); 2,3 gitana.dudzeviciute@vgtu.lt
}

Received 12 March 2017; accepted 11 April 2017

\begin{abstract}
The significance of renewable energy is highly recognized all over the world. However, the impact of consuming renewable energy on the economy is very often disputable and contravercial. The paper explores links between consumption of renewable energy, economic growth, trade, capital and labour. The study covers 28 European Union countries for the period from 1990 to 2012. Energy has been considered as one of production factors, which has a great impact on output. Thus, the neo-classical Cobb-Douglas function has been employed to reach the aim of the article. Following the relevant state-of-art, economic growth, consumption of renewable energy, trade, capital and labour are considered as separate factors. The analysis indicates that consumption of renewable energy boots economy in 12 countries out of 28. The neutrality hypothesis has been confirmed in 2 countries, while the conservation hypothesis has been proved in 6 cases. The weakest links between the consumption of renewable energy and other factors has been noticed in Luxembourgh's case.
\end{abstract}

Keywords: renewable energy, sustainability, economic growth, and employment.

JEL Classification: O44, Q42.

Conference topic: Modern Business Management Problems and Perspectives.

\section{Introduction}

Energy consumption, its efficiency is very often associated with country's competitiveness in the international area, especially industry. Since the industrial revolution people have been trying to reduce production cost and increase profitability. One way to reduce production cost is to use cheaper energy sources. Thus, for a long time producers have been using coal, later oil as primary energy sources. Even currently, production of electricity mostly has been based on fossil fuels (Saidi, Mbarek 2016). However, fossil energy sources might run out much sooner as it is expected. Even more, burning fossil fuels raises $\mathrm{CO}_{2}$ level, which is recognised as exerting a negative impact on the environment and causes the greenhouse effect (Sarkis, Tamarkin 2008). Thus, this resulted to search for alternative energy sources, such as biomass, wind power, photovoltaic, biofuels, geothermal energy, solar thermal energy, biogas, waste, heat pump and small hydro power (Dvorak et al. 2017). Meanwhile, Saidi and Mbarek (2016) claim that future relies on nuclear and renewable energy. They state that the expansion of production technologies based on nuclear energy and renewable energy would significantly reduce future emissions of greenhouse gases emissions. Wind energy as one the most perspective renewable energy sources is seen by Italian scientists. Savino et al. (2017) state that although big wind power plants have reached a relative maturity; however there is a lack of research on profitability of medium wind turbines and their environmental perspective. Meanwhile, Bortolini et al. (2014) claim that small and medium size wind power plants require more investment compared to large ones. Thus, the cost of electricity made by small and medium size wind power plant rises. As Sebri (2015) notes that the sharp and continuous increase in energy prices, the global warming, and running out primary energy sources require that renewable energy would be appropriately managed and used to sustain economic development. Nevertheless, the most of the studies prove that consumption of energy stimulate economic growth, however, at the same time even renewable energy causes environmental degradation. Moreover, renewable energy sometimes is a vital strategic decision for the countries, which have limited fossil energy resources and are dependent on other energy importing countries. The worst situation is when a country becomes reliable on the one particular energy importing country (de Arce et al. 2012). For example, Furouka (2017) notices that the Baltic countries concern energy sustainability because these countries have limited resources and currently they are net importers of oil and natural gas, mainly from Russia.

(C) 2017 A. Šimelytė, G. Dudzevičiūtè. Published by VGTU Press. This is an open-access article distributed under the terms of the Creative Commons Attribution (CC BY 4.0) License, which permits unrestricted use, distribution, and reproduction in any medium, provided the original author and source are credited. 
The aim of the paper is to analyse the relationship between consumption of renewable energy and economic growth. Few additional factors, which might be affected by the consumption of energy, have been included in the study.

\section{Literature review}

A great number of empirical studies focusing on the nexus between energy consumption and economic growth has been published since 1970s the pioneering study by Kraft, A. and Kraft, J. (1978). However, Tiba and Omri (2017) have been analysing 264 globally published scientific sources from 1978 to 2014 and state that various studies provide paradoxes and non-conclusive results which energy consumption might boost economic growth through the productivity enhancement and at the same time it can cause environmental damages.

The nexus between consumption of energy and economic growth is structured around four hypotheses: growth, conservation, feedback, and neutrality. Sebri (2015) quantify synthesises empirical literature by using meta-analysis approach and notices that $32.6 \%$ of all studies confirm both feedback and conservation hypotheses have been supported in $12.6 \%$ of all analysed cases; neutrality and growth hypotheses have been equally proved in $27.4 \%$ of studies. Dogan (2016) claims that different results in studies occur due to selected methodology. He notices that majority of the existing studies use aggregate energy consumption and thus fail to identify the effects of energy consumption by sources on economic growth.

The growth hypothesis suggests that the energy plays a vital role in economic growth directly, so an increase (decrease) in the use of energy leads to an increase (decrease) in the growth of an economy (Dogan 2016). There is unidirectional causality relationally running from energy use to income. Aslan and Ocal (2016) the meaning of growth hypothesis define as the reduction of energy consumption or energy conservation policies, which reduce energy consumption, has a destructive impact on economic growth. Aslan (2016) examines the causality relations among economic growth, biomass energy, employment and capital in the U.S. between 1961 and 2011. The findings of this study support growth hypothesis as the consumption of biomass energy has positive impact on economic growth for the U.S. Inglesi-Lotz (2016) confirms growths hypothesis as well. In the case of OECD countries, the influence of renewable energy consumption or its share to the total energy mix to economic growth is positive and statistically significant. Rafindadi and Ozturk (2016) find that a 1\% increase in renewable energy consumption in Germany would boost its economy by $0.2194 \%$.

According to the conservation hypothesis, the consumption of energy performs a vital role in economic development in both directly and indirectly way. Thus, in this case, there is unidirectional nexus running from economic growth to consuming energy. It means that the reduction of energy use will not affect economic growth adversely. Furouka (2017) analyses the situation in the Baltic States from 1990 to 2011 and confirms the conservation hypothesis. Thus, in the Baltic States the economic development causes the expansion of renewable electricity consumption, but not vice versa.

The feedback hypothesis confirms the existence of bidirectional relationship between output and energy use. This relationship suggests that energy conservation have a negative impact on economic growth and vice versa (Aslan, Ocal 2016). Kahia et al. (2017a) prove existence of bidirectional causal relationship between economic growth and both renewable and non-renewable energy in long-term. However, in MENA countries bidirectional causal association is confirmed between economic growth and renewable energy in short and long term while bidirectional causal relationship between economic growth and non-renewable energy exists only in long-term. Shahbaz et al. (2016) also confirm feedback hypothesis while analysing the consumption of biomass energy and economic development in BRIC countries. The results of this study show the presence of long-run equilibrium relationship between variables. Saidi and Mrabek (2016) discover bidirectional causality between renewable energy and real GDP per capita in the long run and prove unidirectional causality between consumption of renewable energy and real GDP per capita in the short run. Thus, Saidi and Mrabek (2016) conclude that renewable energy is a crucial element for economic growth. Meanwhile, they do not find any links between nuclear energy and real GDP per capita, but unidirectional causality exists between the consumption of nuclear energy and labour. Bidirectional long-term causality between consumption of renewable energy and economic growth has been found in China for the period from 1977-2011. Lin and Moubarak (2014) state that consumption of renewable energy boots economic growth (Fig. 1). Amri (2017) analyses the relationship between economic growth, renewable energy, trade and income by dividing all countries into three groups as per the level of development: whole, developing, high-income developing, upper middle-income developing, lower middle-income developing, lower-income developing, developed, major developed, and others developed countries. The results of study show the feedback linkage between the variables, which means that they are interdependent. In this case, Amri (2017) proves that in both developing and developed countries renewable energy consumption leads to economic growth. A $1 \%$ increase in consuming renewable energy would boost economic growth by $0.873 \%$ in developed countries and by $0.678 \%$ in developing countries.

The neutrality hypothesis denies causal relationship between consumption of energy and economic growth. Under the neutrality hypothesis, the energy consumption reduction will not adversely affect economic growth (Aslan, Ocal 2016). 


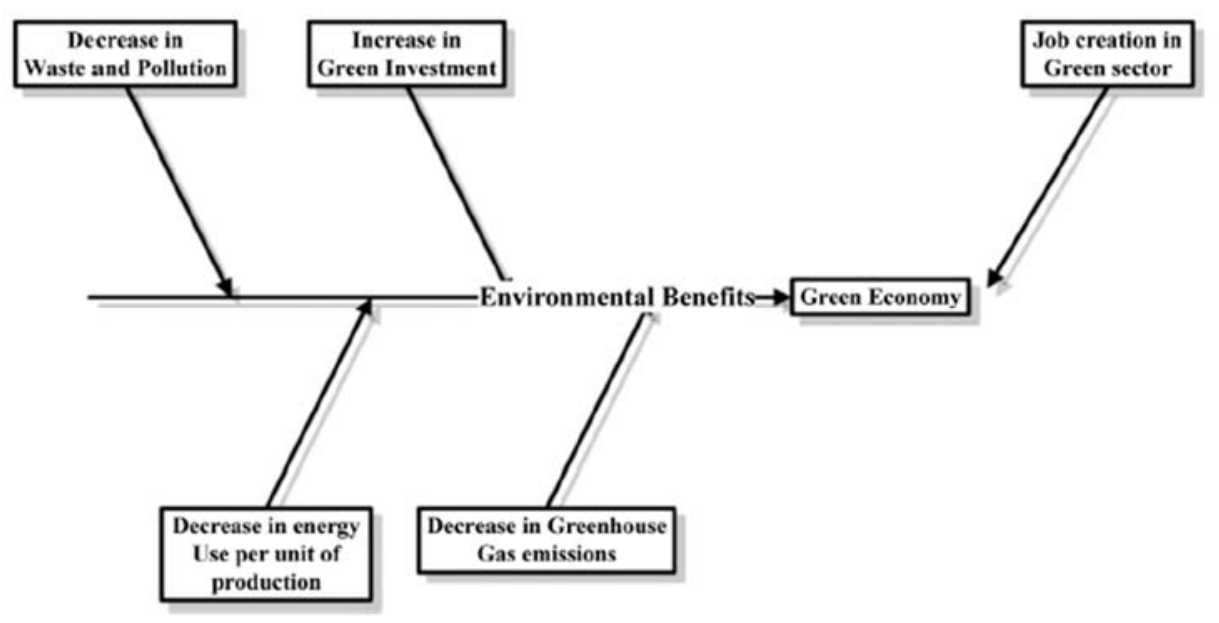

Fig. 1. Progress towards Green Economy (Source: Zeb et al. 2014)

Bhattacharya et al. (2016) confirm the existence of long-run dynamics between economic growth and traditional energy sources, while consumption of renewable energy has positive significant impact on economic growth only in $57 \%$ of all cases. The analysis of Naseri et al. (2016) shows that the increasing consumption of renewable energy in OECD countries leads to economic growth. The same positive affect has been proved in the economy of new EU members (Kahia et al. 2017b). Meanwhile, in OECD countries over the period of 1980-2011, Salim et al. (2014) discover the existence of bidirectional causality between industrial output and consumption of renewable and nonrenewable energy. However, this study shows that unidirectional causality exists between the economic growth and renewable energy. The other group of scientists (Al-Mulali et al. 2014) claims that consumption of electricity from renewable sources is more significant to economic growth then consumption of non-renewable electricity. Al-Mulali et al. (2014) investigate different groups of countries classifying them according to level of incomes: high-income, upper middle income, and lower middle-income countries. However, this analysis provides quite controversial results. The feedback hypothesis is confirmed in $79 \%$ of all cases, $19 \%$ of cases prove neutrality hypothesis and the other $2 \%$ of the countries unveil a one-way long run relationship from economic growth to renewable energy consumption, in this way the conservation hypothesis is being confirmed. Zeb et al. (2014) explore the short and long run causality relationship among electricity production from renewable energy sources, carbon dioxide and depletion of natural resources, poverty and economic growth in SAARC countries over the period of 1975-2010. Bidirectional Granger causality between carbon dioxide emission and natural resources depletion in Nepal and between energy consumption and poverty in Pakistan has been found. Meanwhile, in Bangladesh and India, Granger causality runs from energy consumption to poverty, and from poverty to energy consumption in Sri Lanka. Antonakakis et al. (2017) prove that the effects of the various types of energy consumption on economic growth and $\mathrm{CO}_{2}$ emissions are heterogenours on the various groups of countries. According to Furouka (2017), a country's income and wealth increase if consumption of the renewable electricity expands. This assumption is based on that wealthier countries are able to allocate additional human and financial resources to support their efforts to increase the share of renewable electricity consumption.

\section{Data and Methodological Framework}

The different studies apply various methods for exploring the nexus between economic growth and energy (Table 1). After meta-analysis of empirical studies, Tiba and Omri (2017) notice that Granger causality procedure is the most commonly used tool for exploring the nexus between economic growth and energy consumption. The other researchers use generalized method of moments (Ito 2017), Toda-Yamamoto test (Yildirim et al. 2012), ARDL (Aslan 2016; Naseri et al. 2016; Ito 2017) or ordinary least square method (OLS) model. Hence, Zeb et al. (2014) for examining the short-run and long-run causality relationship among energy consumption, $\mathrm{CO}_{2}$ emissions, GDP, and poverty employ modified ordinary least square model - FMOLS. Ito (2017) explores relationship between $\mathrm{CO}_{2}$ emission, economic growth, and renewable and non-renewable energy for developing countries by employing GMM and pool mean group (PMG). The PMG estimator is based on the ARDL model, which was introduced by Pesaran et al. (1999). Meanwhile, Antonakakis et al. (2017) investigate interrelations in the output-energy-environment nexus by applying panel vector regression (PVAR) and impulse response function on energy consumption (measured as kilotons of oil equivalent per capita), $\mathrm{CO}_{2}$, and real GDP per capita in 106 countries over the period 1971-2011.

In a bulk number of studies the energy consumption has been included into neo-classical Cobb-Douglas production function (Amri 2017; Kahia et al. 2017b; Koçak, Sarkunesi 2017; Bhattacharya et al. 2016; Dogan 2016; InglesiLotz 2016; Rafindadi, Ozturk 2016; Bloch et al. 2015; Shahbaz et al. 2015; Lin, Moubarak 2014). Naseri et al. (2016) determine energy as a factor of production as it has a great impact on output. 
Table 1 . The summary of previous studies on renewable energy consumption and economic growth (Source: composed by the authors)

\begin{tabular}{|c|c|c|c|c|}
\hline Authors & Countries & Period & Methodology & Confirmed hypothesis \\
\hline $\begin{array}{l}\text { Kraft, J. and Kraft, } \\
\text { A. (1978) }\end{array}$ & USA & $1947-1974$ & Granger causality test & Conservation hypothesis \\
\hline \multirow{2}{*}{$\begin{array}{l}\text { Apergis and Payne } \\
(2010)\end{array}$} & \multirow{2}{*}{$\begin{array}{l}20 \text { OECD coun- } \\
\text { tries }\end{array}$} & \multirow{2}{*}{$1985-2005$} & Heterogeneous panel model & Growth hypothesis \\
\hline & & & Granger causality test & Feedback hypothesis \\
\hline \multirow{2}{*}{$\begin{array}{l}\text { Yildirim et al. } \\
\text { (2012) }\end{array}$} & \multirow{2}{*}{ USA } & \multirow{2}{*}{ 1949-2010 } & \multirow{2}{*}{ Toda-Yamamoto test } & $\begin{array}{l}\text { Conservation hypothesis only for bio- } \\
\text { mass-waste-derived energy }\end{array}$ \\
\hline & & & & $\begin{array}{l}\text { Neutrality hypothesis for other re- } \\
\text { newable energy sources }\end{array}$ \\
\hline $\begin{array}{l}\text { Marques and } \\
\text { Fuinhas (2012) }\end{array}$ & $\begin{array}{l}24 \text { European coun- } \\
\text { tries }\end{array}$ & $1990-2007$ & Panel data & Neutrality hypothesis \\
\hline $\begin{array}{l}\text { Al-Mulali et al. } \\
\text { (2013) }\end{array}$ & 103 countries & $1980-2009$ & FMOLS & $\begin{array}{l}79 \% \text { of the countries confirmed feed- } \\
\text { back hypothesis; } 19 \% \text { - neutrality hy- } \\
\text { pothesis; } 2 \% \text { - conservation hypothe- } \\
\text { sis }\end{array}$ \\
\hline $\begin{array}{l}\text { Lin and Moubarak } \\
\text { (2014) }\end{array}$ & China & $1977-2011$ & Cobb-Douglas function & Feedback hypothesis \\
\hline Zeb et al. (2014) & SAARC & $1975-2010$ & FMOLS & Conservation hypothesis \\
\hline \multirow[t]{2}{*}{ Salim et al. (2014) } & \multirow[t]{2}{*}{ OECD countries } & \multirow[t]{2}{*}{$1980-2011$} & $\begin{array}{l}\text { Panel co-integration tech- } \\
\text { niques }\end{array}$ & $\begin{array}{l}\text { Feedback hypothesis confirmed for } \\
\text { industrial output and renewable and } \\
\text { non-renewable energy }\end{array}$ \\
\hline & & & Granger causality test & Growth hypothesis \\
\hline Bloch et al. (2015) & China & $1977-2013$ & $\begin{array}{l}\text { Cobb-Douglas function } \\
\text { Autoregressive distributed } \\
\text { lag VECM }\end{array}$ & Growth hypothesis \\
\hline $\begin{array}{l}\text { Aslan and Ocal } \\
(2016)\end{array}$ & New EU countries & 1990-2009 & $\begin{array}{l}\text { ARDL and asymmetric cau- } \\
\text { sality test }\end{array}$ & $\begin{array}{l}\text { Bulgaria confirms growth hypothesis, } \\
\text { Cyprus, Estonia, Hungary, Poland } \\
\text { and Slovenia - neutrality hypothesis, } \\
\text { Czech Republic - conservation hy- } \\
\text { pothesis }\end{array}$ \\
\hline Naseri et al. (2016) & OECD countries & 1990-2012 & $\begin{array}{l}\text { Time series linear pattern } \\
\text { with Johansen co-integration } \\
\text { test and ARDL model }\end{array}$ & Growth hypothesis \\
\hline Inglesi-Lotz (2016) & OECD countries & 1990-2010 & Cobb-Douglas function & Growth hypothesis \\
\hline $\begin{array}{l}\text { Bhattacharya et al. } \\
(2016)\end{array}$ & $\begin{array}{l}\text { Top } 38 \text { renewable } \\
\text { energy consuming } \\
\text { countries }\end{array}$ & $1997-2012$ & Cobb-Douglas function & $\begin{array}{l}57 \% \text { of all cases confirm growth hy- } \\
\text { pothesis }\end{array}$ \\
\hline Destek (2016) & $\begin{array}{l}\text { Brazil, India, Tur- } \\
\text { key, South Africa, } \\
\text { Mexico, Malaysia }\end{array}$ & $1971-2011$ & $\begin{array}{l}\text { Asymmetric causality ap- } \\
\text { proach }\end{array}$ & $\begin{array}{l}\text { Neutrality hypothesis confirmed for } \\
\text { Brazil and Malaysia, growth hypothe- } \\
\text { sis for South Africa and Mexico, } \\
\text { feedback hypothesis for India }\end{array}$ \\
\hline Aslan (2016) & USA & 1961-2011 & ARDL approach & Growth hypothesis \\
\hline $\begin{array}{l}\text { Shahbaz et al. } \\
(2016)\end{array}$ & BRIC countries & 1991-2015 & Cobb-Douglas function & Feedback hypothesis \\
\hline $\begin{array}{l}\text { Antonakakis et al. } \\
(2017)\end{array}$ & 106 countries & $1971-2011$ & $\begin{array}{l}\text { PVAR and impulse response } \\
\text { function }\end{array}$ & Feedback hypothesis \\
\hline $\begin{array}{l}\text { Koçak and } \\
\text { Sarkgunesi (2017) }\end{array}$ & $\begin{array}{l}9 \text { Black sea and } \\
\text { Balkan countries }\end{array}$ & 1990-2012 & $\begin{array}{l}\text { Cobb-Douglas function with } \\
\text { panel co-integration }\end{array}$ & Feedback hypothesis \\
\hline $\begin{array}{l}\text { Kahia et al. } \\
(2017 \mathrm{a})\end{array}$ & $\begin{array}{l}\text { MENA oil import- } \\
\text { ing countries }\end{array}$ & $1980-2012$ & Granger causality test & Feedback hypothesis \\
\hline $\begin{array}{l}\text { Kahia et al. } \\
(2017 \mathrm{~b})\end{array}$ & MENA countries & $1980-2012$ & Cobb-Douglas function & Feedback hypothesis \\
\hline
\end{tabular}


Some recent studies integrate energy consumption by sources (renewable and non-renewable energy consumption) with the production function (Bhattacharya et al. 2016; Dvorak et al. 2017). Shahbaz et al. (2016) into Cobb-Douglas production function include economic growth expressed as real GDP, consumption of biomass energy, gross capital formation and trade openness. Meanwhile, Inglesi-Lotz (2016) by employing Cobb-Douglas production function includes labour, capital and total factor productivity. Destek (2016) defines real GDP as output; combustible, renewable and waste energy is expressed as the percentage of total energy; the capital is determined by real gross fixed capital, and labour as total employment.

The aim of this research is to provide links between renewable energy consumption, economic growth, trade, and labour force. The study explores 28 European Union countries over the period 1990 to 2012. Following the relevant state-of-the-art, economic growth, renewable energy consumption, trade, capital and labour are considered as separate factors. To reach the aim of the paper, the Cobb-Douglas production function is used:

$$
\begin{aligned}
& y_{i t}=f\left(E_{i t} ; L_{i t} ; K_{i t} ; T_{i t}\right) ; \\
& y_{i t}=A E_{i t}^{\beta_{1 i}} L_{i t}^{\beta_{2 i}} K_{i t}^{\beta 3 i} T_{i t}^{\beta 4 i},
\end{aligned}
$$

where: $i$-stands for the number of cross-sections, $t$ - time period, y-domestic output, $E, L, K, T$ indicate renewable energy, labour, capital, and trade respectively; A - shows level of the technology utilised in the country.

In order to linearize the form of non-linear Cobb-Douglas function, all time series are converted into logarithms. The transformation of data series into natural logarithm avoids the problems associated with dynamics properties of the data series. The log transformation of the data series is preferred approach as cache resulting coefficient in a regression evaluation can be interpreted as elasticity (Bhattacharya et al. 2016).

The empirical equation to investigate the relationship between renewable energy consumption and economic growth is modelled keeping technology as constant. The log-linear specification to assess relationship between renewable energy and economic growth is as follows:

$$
\ln y_{i t}=\alpha+\beta_{1 i} \ln E_{i t}+\beta_{2 i} \ln L_{i t}+\beta_{3 i} \ln K_{i t}+\beta_{4 i} \ln T_{i t}+\varepsilon_{i t},
$$

where $\ln y_{i t}, \ln E_{i t}, \ln L_{i t}, \ln K_{i t}, \ln T_{i t}$ represent logarithms of real GDP per capita, renewable energy consumption (\% of total final energy consumption), employment level, gross fixed capital and exports of goods and services in Euros. $\beta_{1 i}, \beta_{2 i}, \beta_{3 i}, \beta_{4 i}$ are elasticities of output with the respect to renewable energy, labour, gross fixed capital and trade, $\varepsilon_{i t}$-is the error term which supposed to be independently and normally distributed.

All data was obtained from Eurostat database.

\section{Empirical findings}

First results revealed that Sweden, compared to the other European Union countries, would consume the most of renewable energy. The expected ratio is $38.58 \%$ of total energy consumption. The second largest mean among EU countries is in Latvia case (31.8) followed by Finland and Portugal. The least part of consuming renewable energy as the part of final energy is in Malta (0.44). Meanwhile, the highest deviation is noticed in Estonia (7.10), followed by Romania (6.36) and the neighbouring countries Latvia (6.27) and Lithuania (6.46) (Table 2). Lowest deviation has been registered in Malta, France and Luxembourg, which show that the data points would close to expected value.

$R$ and $R^{2}$ tests revealed that the model is significant in all cases and explains more than $90 \%$ of all variability in $\ln Y$ (Table 3 ). The results are provided by $1 \%$ of significance. The simulation of equation 3 shows that consumption of renewable energy in 12 out 28 EU countries would stimulate economic growth. This indicates the growth hypothesis. The neutrality hypothesis is confirmed in Portugal's case, as it does not have relationship between economic growth and renewable energy. The correlation coefficient is only 0.027 . The conservation hypothesis is confirmed in Czech Republic case. In this case, the elasticity's estimation shows that $1 \%$ increase in consuming renewable energy would shrink real GDP per capita by $0.012 \%$, decrease employment level by $0.253 \%$ and capital formation would drop by 0.094 . However, in this case trade would increase by $0.876 \%$. High correlation coefficients confirm the significance of renewable energy.

The strongest relationship (indicated by correlation coefficient) between the consumption of renewable energy and real GDP has been noticed in Czech Republic (0.932), Denmark (0.930), Germany (0.922), Netherlands (0.939) and Slovak Republic (0.942) (Table 4). However, the renewable energy has major impact on real GDP per capita in Netherlands while the lowest effect of renewable energy on economic growth is in Luxembourg. In this case the increase of renewable energy consumption by $1 \%$ would shrink economic growth by $0.022 \%$. The correlation coefficient shows that between consumption of renewable energy and all other factors real GDP per capita, labour, capital, trade are very weak links in Luxembourg case. For example between the consumption of renewable energy and real GDP per capita this coefficient only 0.263 , even lower coefficient is between consumption of renewable energy and labour (0.042). Thus, it might be stated that in Luxembourg the economic growth is boosted by other factors or other business sectors. 
Table 2. Descriptive statistics of renewable energy consumption in the European Union countries (Source: composed by the authors)

\begin{tabular}{|c|c|c|c|c|c|}
\hline & \multirow{2}{*}{$\begin{array}{c}\text { Minimum } \\
\text { Statistic }\end{array}$} & \multirow{2}{*}{$\begin{array}{c}\text { Maximum } \\
\text { Statistic } \\
\end{array}$} & \multicolumn{2}{|c|}{ Mean } & \multirow{2}{*}{$\frac{\text { Std. Deviation }}{\text { Statistic }}$} \\
\hline & & & Statistic & Std. Error & \\
\hline EU & 6.08 & 14.14 & 8.7679 & 0.53991 & 2.41457 \\
\hline Austria & 22.57 & 31.46 & 26.5206 & 0.63245 & 2.75680 \\
\hline Belgium & 0.94 & 5.46 & 2.3048 & 0.34054 & 1.48436 \\
\hline Bulgaria & 1.92 & 14.37 & 7.1387 & 0.94597 & 4.12337 \\
\hline Cyprus & 0.33 & 7.42 & 3.2413 & 0.48376 & 2.10866 \\
\hline Croatia & 12.38 & 21.49 & 16.4105 & 0.53936 & 2.35102 \\
\hline Czech Republic & 2.56 & 10.24 & 5.8787 & 0.48955 & 2.13391 \\
\hline Demark & 7.05 & 23.95 & 12.7322 & 1.26725 & 5.52380 \\
\hline Estonia & 3.36 & 25.13 & 16.2307 & 1.62958 & 7.10317 \\
\hline Finland & 24.13 & 39.12 & 29.9704 & 0.89678 & 4.01051 \\
\hline France & 8.57 & 12.59 & 10.3195 & 0.27277 & 1.21985 \\
\hline Germany & 1.97 & 12.38 & 5.6680 & 0.80988 & 3.62189 \\
\hline Greece & 7.02 & 13.90 & 8.5407 & 0.36885 & 1.64956 \\
\hline Hungary & 3.87 & 10.19 & 5.9670 & 0.41306 & 1.84724 \\
\hline Ireland & 1.90 & 7.09 & 3.1803 & 0.37458 & 1.67516 \\
\hline Italy & 3.78 & 12.09 & 6.0264 & 0.53744 & 2.40352 \\
\hline Latvia & 17.57 & 40.37 & 31.8494 & 1.40373 & 6.27766 \\
\hline Lithuania & 2.89 & 24.28 & 14.7291 & 1.44524 & 6.46331 \\
\hline Luxembourg & 1.27 & 6.85 & 2.9664 & 0.31534 & 1.41025 \\
\hline Malta & 0.13 & 2.61 & 0.4406 & 0.12387 & 0.55398 \\
\hline Netherlands & 1.16 & 4.65 & 2.3030 & 0.27438 & 1.22706 \\
\hline Poland & 2.06 & 11.08 & 6.8175 & 0.54168 & 2.42245 \\
\hline Portugal & 18.07 & 27.82 & 23.5336 & 0.62615 & 2.80025 \\
\hline Romania & 3.35 & 24.10 & 14.6060 & 1.42434 & 6.36984 \\
\hline Slovak Republic & 2.09 & 10.48 & 5.9045 & 0.62364 & 2.78901 \\
\hline Slovenia & 10.23 & 19.32 & 14.3234 & 0.55192 & 2.46828 \\
\hline Spain & 7.29 & 15.75 & 9.9180 & 0.55094 & 2.46390 \\
\hline Sweden & 31.35 & 49.91 & 38.5848 & 1.31157 & 5.86551 \\
\hline
\end{tabular}

Although in Austria, the consumption of renewable energy would have positive impact; however, an increase of renewable energy by $1 \%$, would boost economic growth only by $0.079 \%$. Even more, the correlation coefficient in Austria's case indicates moderately strong relationship (0.660).

Table 3. Results of Equation 3 (Source: composed by the authors)

\begin{tabular}{ccccccc}
\hline & Energy & Labour & Capital & Trade & $\mathrm{R}$ & $\mathrm{R}^{2}$ \\
\hline \multirow{2}{*}{ EU } & -0.130 & 0.103 & -0.848 & 1.825 & 0.949 & 0.874 \\
& $(-0.487)$ & $(0.556)$ & $(-0.966)$ & $(0.925)$ & & \\
\hline \multirow{2}{*}{ Austria } & 0.079 & -0.115 & -0.525 & 1.477 & 0.954 & 0.910 \\
& $(0.561)$ & $(0.785)$ & $(-1.604)$ & $(4.024)$ & & \\
\hline \multirow{2}{*}{ Belgium } & 0.427 & -0.059 & -0.727 & 1.327 & 0.950 & 0.903 \\
& $(1.853)$ & $(-1,195)$ & $(-1.265)$ & $(3.235)$ & & \\
\hline \multirow{2}{*}{ Bulgaria } & 0.230 & -0.026 & 0.741 & 0.052 & 0.967 & 0.935 \\
& $(0.893)$ & $(-0.148)$ & $(2.329)$ & $(0.501)$ & & \\
\hline \multirow{2}{*}{ Cyprus } & -0.113 & 0.465 & 0.306 & 0.414 & 0.952 & 0.905 \\
& $(-0.495)$ & $(2.809)$ & $(2.173)$ & $(1.752)$ & & \\
\hline
\end{tabular}


Continued Table 3

\begin{tabular}{|c|c|c|c|c|c|c|}
\hline & Energy & Labour & Capital & Trade & $\mathrm{R}$ & $\mathrm{R}^{2}$ \\
\hline Croatia & $\begin{array}{c}-0.115 \\
(-2.353)\end{array}$ & $\begin{array}{c}0.148 \\
(2.617)\end{array}$ & $\begin{array}{c}0.157 \\
(1.688)\end{array}$ & $\begin{array}{c}0.914 \\
(10.329)\end{array}$ & 0.987 & 0.974 \\
\hline Czech Republic & $\begin{array}{c}-0.012 \\
(-0.045)\end{array}$ & $\begin{array}{c}-0.253 \\
(-2.287)\end{array}$ & $\begin{array}{c}-0.094 \\
(-0.406)\end{array}$ & $\begin{array}{c}0.876 \\
(3.022)\end{array}$ & 0.967 & 0.935 \\
\hline Demark & $\begin{array}{c}0.231 \\
(0.477)\end{array}$ & $\begin{array}{c}0.251 \\
(1.799)\end{array}$ & $\begin{array}{c}-0.878 \\
(-1.656)\end{array}$ & $\begin{array}{c}1.456 \\
(1.671)\end{array}$ & 0.961 & 0.923 \\
\hline Estonia & $\begin{array}{c}0.191 \\
(1.514)\end{array}$ & $\begin{array}{c}0.294 \\
(4.080)\end{array}$ & $\begin{array}{c}0.621 \\
(9.104)\end{array}$ & $\begin{array}{c}0.411 \\
(3.761)\end{array}$ & 0.985 & 0.971 \\
\hline Finland & $\begin{array}{c}0.194 \\
(0.854)\end{array}$ & $\begin{array}{c}0.020 \\
(0.060)\end{array}$ & $\begin{array}{c}0.423 \\
(0.672)\end{array}$ & $\begin{array}{c}0.338 \\
(0.839) \\
\end{array}$ & 0.927 & 0.860 \\
\hline France & $\begin{array}{c}0.218 \\
(1.872)\end{array}$ & $\begin{array}{c}0.207 \\
(0.664)\end{array}$ & $\begin{array}{c}0.031 \\
(0.053)\end{array}$ & $\begin{array}{c}0.699 \\
(1.907)\end{array}$ & 0.943 & 0.888 \\
\hline Germany & $\begin{array}{c}0.220 \\
(0.514)\end{array}$ & $\begin{array}{c}-0.149 \\
(-1.833)\end{array}$ & $\begin{array}{c}-0.226 \\
(-1,746)\end{array}$ & $\begin{array}{c}0.895 \\
(1.788)\end{array}$ & 0.950 & 0.902 \\
\hline Greece & $\begin{array}{c}-0.135 \\
(-1.422)\end{array}$ & $\begin{array}{c}0.490 \\
(2.866)\end{array}$ & $\begin{array}{c}-0.135 \\
(-0.409)\end{array}$ & $\begin{array}{c}0.686 \\
(2.190)\end{array}$ & 0.950 & 0.903 \\
\hline Hungary & $\begin{array}{c}-0.417 \\
(-1.375)\end{array}$ & $\begin{array}{c}-0.031 \\
(-0.376)\end{array}$ & $\begin{array}{c}0.267 \\
(0.970)\end{array}$ & $\begin{array}{l}1.056 \\
(2.12)\end{array}$ & 0.962 & 0.928 \\
\hline Ireland & $\begin{array}{c}-0.431 \\
(-1.352)\end{array}$ & $\begin{array}{c}-0.248 \\
(-0.553)\end{array}$ & $\begin{array}{c}0.410 \\
(0.915)\end{array}$ & $\begin{array}{c}1.109 \\
(2.966)\end{array}$ & 0.966 & 0.932 \\
\hline Italy & $\begin{array}{c}0.118 \\
(1.130) \\
\end{array}$ & $\begin{array}{c}0.166 \\
(0.637) \\
\end{array}$ & $\begin{array}{c}0.637 \\
(1.400)\end{array}$ & $\begin{array}{c}0.115 \\
(0.379)\end{array}$ & 0.952 & 0.907 \\
\hline Latvia & $\begin{array}{c}-0.331 \\
(-2.651)\end{array}$ & $\begin{array}{c}0.060 \\
(0.828)\end{array}$ & $\begin{array}{c}0.547 \\
(6.866) \\
\end{array}$ & $\begin{array}{c}0.779 \\
(7.355)\end{array}$ & 0.983 & 0.967 \\
\hline Lithuania & $\begin{array}{c}-0.157 \\
(-0.712)\end{array}$ & $\begin{array}{c}0.035 \\
(0.325)\end{array}$ & $\begin{array}{c}0.333 \\
(3.210)\end{array}$ & $\begin{array}{c}0.852 \\
(4.616)\end{array}$ & 0.976 & 0.952 \\
\hline Luxembourg & $\begin{array}{c}-0.022 \\
(-0.252)\end{array}$ & $\begin{array}{c}-0.078 \\
(-0.600)\end{array}$ & $\begin{array}{c}-0.218 \\
(-0.506)\end{array}$ & $\begin{array}{c}1.241 \\
(2.736)\end{array}$ & 0.959 & 0.919 \\
\hline Malta & $\begin{array}{c}0.427 \\
(3.845)\end{array}$ & $\begin{array}{c}-0.287 \\
(-1.893)\end{array}$ & $\begin{array}{c}0.438 \\
(2.691)\end{array}$ & $\begin{array}{c}0.055 \\
(0.299)\end{array}$ & 0.927 & 0.859 \\
\hline Netherlands & $\begin{array}{c}0.559 \\
(1.610)\end{array}$ & $\begin{array}{c}0.424 \\
(1.803)\end{array}$ & $\begin{array}{c}-0.596 \\
(-1.821)\end{array}$ & $\begin{array}{c}0.595 \\
(0.904)\end{array}$ & 0.966 & 0.933 \\
\hline Poland & $\begin{array}{c}-0.125 \\
(-1.142)\end{array}$ & $\begin{array}{c}-0.290 \\
(-4.353)\end{array}$ & $\begin{array}{c}-0.713 \\
(-4,476)\end{array}$ & $\begin{array}{c}1.666 \\
(10.185)\end{array}$ & 0.985 & 0.970 \\
\hline Portugal & $\begin{array}{c}-0.300 \\
(-1.784)\end{array}$ & $\begin{array}{c}0.073 \\
(0.584)\end{array}$ & $\begin{array}{c}-0.586 \\
(-1.690)\end{array}$ & $\begin{array}{c}1.404 \\
(5.211)\end{array}$ & 0.955 & 0.911 \\
\hline Romania & $\begin{array}{c}-0.424 \\
(-2.145)\end{array}$ & $\begin{array}{c}0.004 \\
(0.037)\end{array}$ & $\begin{array}{c}-0.184 \\
(-1.504)\end{array}$ & $\begin{array}{c}1.516 \\
(4.764)\end{array}$ & 0.981 & 0.953 \\
\hline Slovak Republic & $\begin{array}{c}0.090 \\
(0.596)\end{array}$ & $\begin{array}{c}-0.078 \\
(-1.448)\end{array}$ & $\begin{array}{c}0.014 \\
(0.133)\end{array}$ & $\begin{array}{c}0.855 \\
(4.944)\end{array}$ & 0.983 & 0.967 \\
\hline Slovenia & $\begin{array}{c}-0.387 \\
(-2.156)\end{array}$ & $\begin{array}{c}0.140 \\
(1.079)\end{array}$ & $\begin{array}{c}0.965 \\
(3.620)\end{array}$ & $\begin{array}{c}0.185 \\
(0.639)\end{array}$ & 0.945 & 0.892 \\
\hline Spain & $\begin{array}{c}-0.245 \\
(-1.707)\end{array}$ & $\begin{array}{c}0.434 \\
(1.987)\end{array}$ & $\begin{array}{c}0.983 \\
(3.444)\end{array}$ & $\begin{array}{c}-0.280 \\
(-1.371)\end{array}$ & 0.973 & 0.966 \\
\hline Sweden & $\begin{array}{c}-0.040 \\
(-0.153)\end{array}$ & $\begin{array}{c}-0.090 \\
(-0.784)\end{array}$ & $\begin{array}{c}0.617 \\
(2.770)\end{array}$ & $\begin{array}{c}0.443 \\
(1.982)\end{array}$ & 0.941 & 0.886 \\
\hline
\end{tabular}


The lowest long-term bivariate correlation coefficient exists in Luxembourg followed by Croatia, France and Portugal. In most of cases, the strongest links are noticed between renewable energy and trade. The most notable negative impact out of all EU countries, renewable energy would have on the economic growth in Hungary, Ireland, Latvia and Slovenia, where $1 \%$ of decrease on consuming renewable energy would shrink economic growth by $0.417 \%, 0.431 \%$, $0.331 \%$, and $0.387 \%$ respectively. Moreover, the correlation coefficient indicates moderately strong links between renewable and real GDP per capita in these countries, $0.703,0.648,0.681$, and 0.613 respectively. The weakest links between the consumption of renewable energy and other factors in long-term have been registered in Croatia. Even elasticity shows that increase in consuming $1 \%$ of renewable energy would decline economic growth by $0.113 \%$. However, such low correlation coefficients confirm the neutrality hypothesis in Croatia case. Although, 16 out of EU countries have negative elasticity of $\operatorname{lnE}$; however, in some cases, the correlation coefficient between renewable energy and trade indicate strong relationship in long-term period, which means that renewable energy might have positive influence on the economic growth in the future.

Table 4. Correlation coefficient between renewable energy and other independent factors (Source: composed by the authors)

\begin{tabular}{|c|c|c|c|c|}
\hline & GDP & Labour & Capital & Trade \\
\hline $\mathrm{EU}$ & 0.874 & 0.684 & 0.888 & 0.925 \\
\hline Austria & 0.660 & 0.783 & 0.521 & 0.639 \\
\hline Belgium & 0.871 & 0.880 & 0.926 & 0.881 \\
\hline Bulgaria & 0.894 & 0.256 & 0.869 & 0.531 \\
\hline Cyprus & 0.812 & 0.736 & 0.734 & 0.863 \\
\hline Croatia & -0.201 & 0.261 & -0.303 & -0.084 \\
\hline Czech Republic & 0.932 & -0.745 & 0.938 & 0.963 \\
\hline Demark & 0.930 & 0.212 & 0.849 & 0.955 \\
\hline Estonia & 0.787 & -0.662 & 0.701 & 0.863 \\
\hline Finland & 0.840 & 0.431 & 0.793 & 0.892 \\
\hline France & 0.233 & 0.093 & 0.166 & -0.014 \\
\hline Germany & 0.922 & -0.005 & 0.632 & 0.972 \\
\hline Greece & 0.361 & 0.470 & 0.529 & 0.429 \\
\hline Hungary & 0.703 & -0.191 & 0.636 & 0.895 \\
\hline Ireland & 0.648 & 0.424 & 0.750 & 0.790 \\
\hline Italy & 0.685 & 0.433 & 0.586 & 0.631 \\
\hline Latvia & 0.681 & -0.632 & 0.748 & 0.824 \\
\hline Lithuania & 0.864 & -0.724 & 0.814 & 0.910 \\
\hline Luxembourg & 0.263 & 0.042 & 0.190 & 0.266 \\
\hline Malta & 0.652 & -0.163 & 0.399 & 0.224 \\
\hline Netherlands & 0.939 & 0.770 & 0.855 & 0.947 \\
\hline Poland & 0.812 & -0.434 & 0.833 & 0.877 \\
\hline Portugal & 0.027 & -0.407 & -0.473 & 0.056 \\
\hline Romania & 0.821 & -0.423 & 0.745 & 0.912 \\
\hline Slovak Republic & 0.942 & -0.412 & 0.849 & 0.942 \\
\hline Slovenia & 0.613 & 0.388 & 0.829 & 0.938 \\
\hline Spain & 0.492 & 0.352 & 0.729 & 0.438 \\
\hline Sweden & 0.871 & 0.127 & 0.880 & 0.851 \\
\hline
\end{tabular}

On the whole, in the EU the consumption of renewable energy and economic growth has strong relationship; however the growth of consuming renewable energy by $1 \%$ would shrink EU economic growth by $0.130 \%$. The strong relationship has been registered between consumption of renewable energy and trade, capital formation. However, moderately strong link has been indicated between renewable energy and employment level in EU. 


\section{Conclusions}

The analysis of various scientific studies provides controversial results. Moreover, different results have been obtained by analysing the same countries over the same period of time. This might be explained that different scientists employ different methodology. The study on employed methods has revealed that the most popular are Granger causality test, AFD test and Cobb-Douglas production function transform into natural logarithm form.

Based on analysis of various methods, Cobb-Douglas production function has been applied for the study. Results of $\mathrm{R}$ and $\mathrm{R}^{2}$ have shown that the created model is significant in all cases. The analysis indicates that consumption of renewable energy boosts economic growth in 12 countries out of 28 . However, the opposite result has been noticed in the case of European Union economy. Although, correlation coefficient indicates strong relationship between consumption of renewable energy and real GDP per capita of EU; however a $1 \%$ increase of renewable energy would shrink all economy by $0.13 \%$.

The growth hypothesis has been confirmed in 12 cases, the neutrality hypothesis has been indicated in Luxembourg, Portugal. The conservation hypothesis has been proved in Czech Republic, Hungary, Latvia, Lithuania, Romania, and Spain cases.

The results reveal that almost in all cases the strongest relationship has been registered between consumption of renewable energy and trade. Meanwhile, the other factors demonstrated different links with consumption of renewable energy.

\section{References}

Al-Mulali, U.; Fereidouni, H. G.; Lee, J. Y. 2014. Electricity consumption from renewable and non-renewable sources and economic growth: evidence from Latin American countries, Renewable and Sustainable Energy Reviews 30: 290-298. https://doi.org/10.1016/j.rser.2013.10.006

Al-Mulali, U.; Fereidouni, H. G.; Lee, J. Y.; Che Sab, Ch. N. B. 2013. Examining the bi-directional long run relationship between renewable energy consumption and GDP growth, Renewable and Sustainable Energy Reviews 22: 209-222. https://doi.org/10.1016/j.rser.2013.02.005

Amri, F. 2017. Intercourse across economic growth, trade and renewable energy consumption in developing and developed countries, Renewable and Sustainable Energy Reviews 69: 527-534. https://doi.org/10.1016/j.rser.2016.11.230

Antonakakis, N.; Chatziantoniou, I.; Filis, G. 2017. Energy consumption, CO2 emissions, and economic growth: an ethical dilemma, Renewable and Sustainable Energy Reviews 68: 808-824. https://doi.org/10.1016/j.rser.2016.09.105

Apergis, N.; Payne, J. E. 2010. Renewable energy consumption and economic growth: Evidence from a panel of OECD countries, Energy Policy 38(2): 656-660. https://doi.org/10.1016/j.enpol.2009.09.002

Aslan, A. 2016. The causal relation ship between biomass energy use and economic growth in the United States, Renewable and Sustainable Energy Reviews 57: 362-366. https://doi.org/10.1016/j.rser.2015.12.109

Aslan, A.; Ocal, O. 2016. The role of renewable energy consumption in economic growth: evidence from asymmetric causality, Renewable and Sustainable Energy Reviews 60: 953-959. https://doi.org/10.1016/j.rser.2016.01.123

Bhattacharya, M.; Paramati, S. R.; Ozturk, I.; Bhattacharya, S. 2016. The effect of renewable energy consumption on economic growth: evidence from top 38 countries, Applied Energy 162: 733-741. https://doi.org/10.1016/j.apenergy.2015.10.104

Bloch, H.; Rafiq, S.; Salim, R. 2015. Economic growth with coal, oil and renewable energy consumption in China: prospects for fuel substitution, Economic Modelling 44: 104-115. https://doi.org/10.1016/j.econmod.2014.09.017

Bortolini, M.; Gamberi, M.; Graziani, A.; Manzini, R. 2014. Performance and viability analysis on small wind turbines in the European Union, Renewable Energy 62: 629-39. https://doi.org/10.1016/j.renene.2013.08.004

de Arce, R.; Mahia, R.; Medina, A.; Escribano, G. 2012. A simulation of the economic impact of renewable energy development in Morocco, Energy Policy 46: 335-345. https://doi.org/10.1016/j.enpol.2012.03.068

Destek, M. A. 2016. Renewable energy consumption and economic growth in newly industrialized countries: evidence from asymmetric causality test, Renewable Energy 95: 478-484. https://doi.org/10.1016/j.renene.2016.04.049

Dogan, E. 2016. Analyzing the linkage between renewable and non-renewable energy consumption and economic growth by considering structural break in time-series data, Renewable Energy 99: 1126-1136. https://doi.org/10.1016/j.renene.2016.07.078

Dvorak, P.; Martinat, S.; der Horst, D. V.; Frantald, B.; Turečkova, K. 2017. Renewable energy investment and job creation; a cross-sectoral assessment for the Czech Republic with reference to EU benchmark, Renewable and Sustainable Energy Reviews 69: 360-368. https://doi.org/10.1016/j.rser.2016.11.158

Furouka, F. 2017. Renewable electricity consumption and economic development: new findings from the Baltic countries, Renewable and Sustainable Energy Reviews 71: 450-463. https://doi.org/10.1016/j.rser.2016.12.074

Inglesi-Lotz, R. 2016. The impact of renewable energy consumption to economic growth: a panel data application, Energy Economics 53: 58-63. https://doi.org/10.1016/j.eneco.2015.01.003

Ito, K. 2017. $\mathrm{CO}_{2}$ emissions, renewable and non-renewable energy consumption, and economic growth: evidence from panel data for developing countries, International Economics (article in press). https://doi.org/10.1016/j.inteco.2017.02.001

Kahia, M.; Aïssa, M. S. B.; Lanouarb, Ch. 2017a. Renewable and non-renewable energy use - economic growth nexus: the case of MENA Net Oil Importing Countries, Renewable and Sustainable Energy Reviews 7: 127-140. https://doi.org/10.1016/j.rser.2017.01.010 
Kahia, M.; Kadria, M.; Aissa, M. S. B.; Lanouar, Ch. 2017b. Modelling the treatment effect of renewable energy policies on economic growth: evaluation from MENA countries, Journal of Cleaner Production 149: 845-855. https://doi.org/10.1016/j.jclepro.2017.02.030

Koçak, E.; Şarkgüneşi, A. 2017. The renewable energy and economic growth nexus in Black Sea and Balkan, Energy policy 100(1): $51-57$.

Kraft, J.; Kraft, A. 1978. On the relationship between energy and GNP, Journal of Energy and Development 3(2): $401-403$.

Lin, B.; Moubarak, M. 2014. Renewable energy consumption - economic growth nexus for China, Renewable and Sustainable Energy Reviews 40: 111-117. https://doi.org/10.1016/j.rser.2014.07.128

Marques, A. C.; Fuinhas, J. A. 2012. Is renewable energy effective in promoing growth? Energy Policy 46(1): 434-442. https://doi.org/10.1016/j.enpol.2012.04.006

Naseri, S. F. Motamedi, S.; Ahmadian, M. 2016. Study of mediated consumption effect of Renewable Energy on Economic Growth of OECD countries, Procedia Economics and Finance 36: 502-509. https://doi.org/10.1016/S2212-5671(16)30068-5

Pesaran, M. H.; Shin, Y.; Smith, R. 1999. Pooled mean group estimation of dynamic heterogeneous panels, Journal of American Statistical Association 94: 621-634. https://doi.org/10.1080/01621459.1999.10474156

Rafindadi, A. A.; Ozturk, I. 2016. Impacts of renewable energy consumption on the German economic growth: evidence from combined cointegration test, Renewable and Sustainable Energy Reviews (article in press).

Saidi, K.; Mrabek, M. B. 2016. Nuclear energy, renewable energy, CO2 emissions, and economic growth for nine developed countries: evidence from panel Granger causality tests, Progress in Nuclear Energy 88: 364-374. https://doi.org/10.1016/j.pnucene.2016.01.018

Salim, R. A.; Hassan, K.; Sahar Shafiei, S. 2014. Renewable and non-renewable energy consumption and economic activities: Further evidence from OECD countries, Energy Economics 44: 350-360. https://doi.org/10.1016/j.eneco.2014.05.001

Sarkis, J.; Tamarkin, M. 2008. Real options analysis for renewable energy technologies in a ghg emissions trading environment, in Antes R. Hansjürgens, B.; Letmathe, P. (Eds.). Emissions trading. New York: Springer, 103-119.

Savino, M. M.; Manzini, R.; Della Selva, V.; Accorsi, R. 2017. A new model for environmental and economic evaluation of renewable energy systems: the case of wind turbines, Applied Energy 189: 739-752. https://doi.org/10.1016/j.apenergy.2016.11.124

Sebri, M. 2015. Use renewables to be cleaner: meta-analysis of the renewable energy consumption-economic growth nexus, Renewable and Sustainable Energy Reviews 42: 657-665. https://doi.org/10.1016/j.rser.2014.10.042

Shahbaz, M.; Loganathan, N; Zeshan, M.; Zaman, K. 2015. Does renewable energy consumption add in economic growth? An application of auto-regressive distributed lag model in Pakistan, Renewable and Sustainable Energy Reviews 44: 576-585. https://doi.org/10.1016/j.rser.2015.01.017

Shahbaz, M.; Rasool, G.; Ahmed, K.; Mahalik, M. K. 2016. Considering the effect of biomass energy consumption on economic growth: fresh evidence from BRICS region, Renewable and Sustainable Energy Reviews 60: 1442-1450. https://doi.org/10.1016/j.rser.2016.03.037

Tiba, S.; Omri, A. 2017. Literature survey on the relationships between energy, environment and economic growth, Renewable and Sustainable Energy Reviews 69: 1129-1146. https://doi.org/10.1016/j.rser.2016.09.113

Yildirim, E.; Sarac, S.; Aslan, A. 2012. Energy consumption and economic growth in the USA: evidence from renewable energy, Renewable and Sustainable Energy Reviews 16(9): 6770-6774. https://doi.org/10.1016/j.rser.2012.09.004

Zeb, R.; Salar, L.; Awan, U.; Zaman, K.; Shahbaz, M. 2014. Causal links between renewable energy, environmental degradation and economic growth in selected SAARC countries: progress towards green economy, Renewable Energy 71:123-132. https://doi.org/10.1016/j.renene.2014.05.012 